\title{
KELAYAKAN USAHA BUDIDAYA AYAM PETELUR (Analisis Biaya Manfaat dan BEP pada UD KR Farm, Cilacap)
}

\author{
Muhamad Rijal Pamungkas" ${ }^{* 1}$, Sri Rahayu ${ }^{2}$ \\ ${ }^{1}$ Program Studi Ekonomi Pembangunan Fakultas Ekonomi; Universitas Nahdlatul Ulama Al Ghazali \\ Cilacap \\ ${ }^{2}$ Program Studi Manajemen Fakultas Ekonomi; Universitas Nahdlatul Ulama Al Ghazali Cilacap \\ Email : "1mr.pamungkas84@gmail.com
}

\begin{abstract}
In the implementation of a livestock business, the use of production factors such as feed, efficiently becomes a benchmark in determining the profits derived from the business. This study aims (1) to determine the effect of feed prices on egg production (2) to determine the financial feasibility of the business in terms of cost and benefit analysis and how much BEP (Break Event Point) of laying hens. The data used are production data and feed prices for the period January 2019 - December 2019 at the KR Farm farm, Kuripan Kidul, Kesugihan, Cilacap. The data analysis technique uses regression analysis. The results of this study found that there was an effect of the price of feed on egg production, KR Farm said to be feasible where it obtained an $R / C$ value of 2.69, while the value of $B / C=1.69, B E P$ (price) Rp. 438.49 items, BEP (production) of 454,281.74 items, and ROI of 1,69\%. Suggestions that can be put forward in this study include, preferably the KR Farm can maintain its business that has good and decent performance so far, if seen from the price of feed it will further maintain its egg production, can also increase the profits obtained by increasing the number of laying hens in the future so that the increase in turnover obtained is $R p$. 1,783,592,221 per month, and reduce the amount of BEP that can be done by increasing the selling price of eggs or by reducing total costs.
\end{abstract}

Keywords: Laying hens, Egg production, Feed prices, Cost and Benefit analysis, Break Even Point analysis

\section{PENDAHULUAN}

Tingkat kesejahteraan masyarakat dapat dilihat dari beberapa indikator diantaranya tingkat kecukupan gizi, yang dihitung berdasarkan besar kalori dan protein yang dikonsumsi. Standar yang digunakan untuk menentukan tingkat kecukupan konsumsi kalori dan protein masyarakat Indonesia per kapita per hari berdasarkan Peraturan Menteri Kesehatan Republik Indonesia Nomor 75 Tahun 2013 Tentang Angka Kecukupan Gizi yang dianjurkan bagi bangsa Indonesia adalah $2.150 \mathrm{kkal}$ dan 57 gram protein. Rata-rata konsumsi kalori penduduk Indonesia pada tahun 2017 sebesar 2.152,64 kkal berada di atas standar kecukupan begitu juga untuk konsumsi protein sebesar 62,20 gram, sudah berada di atas standar kecukupan (Hakiki, 2018).

Usaha ternak ayam petelur merupakan sub sektor utama penghasil telur di Indonesia, seiring dengan berkembangnya teknologi, usaha ternak menjadi sorotan dibanyak kalangan dan menjadi inti permasalahan di setiap media sosial, sebab kehadiran usaha ternak mampu 
memberikan dampak terhadap kehidupan di Indonesia, salah satu dampak positif yaitu peternakan mampu menyediakan kebutuhan akan konsumen seperti produk segar maupun olahan yang berasal dari telur ayam, di sisi lain ada dampak negatif yang ditimbulkan yaitu limbah peternakan yang belum mampu dimanfaatkan sehingga mencemari lingkungan seperti bau dan kotoran.

Yunus (2009) mengatakan sektor peternakan merupakan salah satu sektor penyedia pangan utama untuk menopang pertumbuhan industri. Hingga saat ini sektor peternakan sebagai mesin penggerak pembangunan nasional maupun daerah memegang peranan penting dalam perekonomian masyarakat.

Perkembangan usaha peternakan unggas di Indonesia relatif lebih maju bila dibandingkan dengan usaha peternakan lainnya. Berdasarkan data sensus pertanian 2013 jumlah usaha peternakan unggas yang meliputi ternak ayam lokal, ayam ras petelur, ayam ras pedaging, itik, dan itik manila adalah 7,77 juta unit (Badan Pusat Statistik, 2013).

Kontribusi peternakan unggas dalam menyumbang swasembada protein hewani terutama dalam pemenuhan kebutuhan makanan cukup tinggi. Peternakan unggas juga berperan sebagai sumber pendapatan, membuka kesempatan kerja, dan sebagai sumber protein hewani. Peternakan unggas menjadi usaha yang paling diminati karena selain pemeliharaan lebih mudah, perputaran investasi lebih cepat. Salah satu ternak unggas yang dipelihara oleh peternak yang ada di Indonesia adalah ayam petelur.

Populasi ternak ayam petelur semakin meningkat dari tahun ke tahun khususnya pada Provinsi Jawa Tegah. Kabupaten Cilacap merupakan salah satu kabupaten yang ada di Jawa Tengah yang berpotensi mengembangkan usaha ternak ayam petelur, akan tetapi masih sedikit dalam populasi ternak ayam petelur dan hanya menyumbang sekitar 30-45\% hasil akan telur di Kabupaten Cilacap. Bahkan untuk mengisi kekurangan jumlah telur harus dikirim dari kabupaten tetangga tepatnya dari Kecamatan Cilongok Kabupaten Banyumas.

Studi kelayakan adalah penelitian dan analisis terhadap suatu rencana usaha yang menyangkut berbagai aspek, termasuk aspek pemasaran, operasi, SDM, yuridis, lingkungan, dan keuangan, sehingga diketahui rencana usaha tersebut layak atau tidak layak bila dilaksanakan (R.W. Suparyanto, 2016).

Ayam petelur merupakan segala jenis bangsa ayam yang mampu menghasilkan telur untuk memenuhi kebutuhan akan protein manusia. Mengingat bahwa betapa pentingnya penyediaan telur ayam sehingga banyak peternak-peternak membangun sebuah usaha peternakan ayam petelur. Namun di lain sisi banyak peternak yang akhirnya gulung tikar sebab sebagian dari peternakan tidak memahami bagaimana manajemen beternak yang baik, efisien, dan menguntungkan.

Perlu diketahui bahwa berternak ayam petelur memiliki siklus. Siklus terebut dapat terbagi menjadi 3 periode dalam setahun yaitu ayam muda, ayam potensial (ayam produktif), serta ayam menurun produksi telurnya, dapat dilihat pada gambar di bawah ini: 


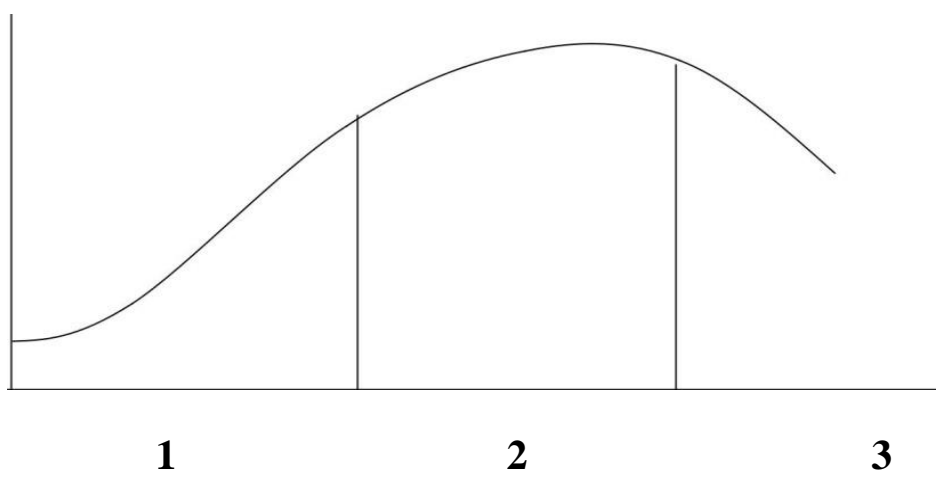

Gambar 1. Siklus Ayam

Seorang peternak ayam petelur untuk mengetahui tahapan-tahapan diatas, pada awalnya ayam hanya berjumlah sekitar 5.000 ekor dan pada siklus hidup tertentu sebelum produksi telur menurun, maka dapat ditambahkan ayam muda sebagai replanting (penyegaran), selain itu sebaiknya juga membagi ayam ke dalam beberapa periode usia ayam guna menjaga siklus usia ayam sehingga dapat memperbaiki kualitas hasil produksi telur.

Tujuan penelitian ini adalah (1) untuk mengetahui apakah harga pakan ayam dapat mempengaruhi terhadap produksi telur tersebut, (2) untuk mengetahui analisi finansial usaha dari sisi BEP, ROI, R/C ratio, B/C ratio, NPV, IRR, Payback Periode.

Setelah mengetahui siklus ayam petelur, maka akan membuat seorang peternakan menjadi paham dan lebih maju dalam produksi telurnya sekaligus meningkatkan keuntungan yang diperolehnya di masa mendatang, sehingga hal inilah yang melatar belakangi penulis dalam menulis dengan judul "Kelayakan Usaha Budidaya Ayam Petelur (Analisis Biaya Manfaat dan BEP pada UD KR Farm, Cilacap)

\section{METODE PENELITIAN}

\section{Lokasi Penelitian}

Penelitian ini berlokasi di Jalan Menur Desa Kuripan Kidul, Kecamatan Kesugihan, Kabupaten Cilacap Provinsi Jawa Tengah Tahun 2017 - 2019.

\section{Jenis Dan Sumber Data}

Peneliti menggunakan metode studi kasus. Studi kasus ialah salah satu metode penelitian dalam ilmu sosial. Riset yang menggunakan metode ini, dilakukan pemeriksaan longitudinal yang mendalam terhadap suatu keadaan atau kejadian yang disebut sebagai kasus dengan menggunakan cara-cara yang sistematis dalam melakukan pengamatan, pengumpulan data, analisis informasi, dan pelaporan hasilnya. Studi kasus pada penelitian ini menggunakan obyek penelitian yaitu pada KR Farm, Kuripan Kidul, Kesugihan, Cilacap.

Jenis data yang digunakan dalam penelitian ini adalah data primer dan sekunder. Data primer terdiri dari harga pakan, harga telur, jumlah produksi, dan fixed cost dan variable cost. Sumber data diperoleh berasal dari perusahaan KR Farm. Adapun data yang diambil meliputi time series 3 (tiga) tahun periode bulanan. Sedangkan data sekunder diperoleh dari instansi pemerintah atau swasta dan artikel-artikel yang berkaitan dengan usaha peternakan ayam petelur. 


\section{Definisi Operasional Variabel}

Definisi operasional adalah suatu definisi yang diberikan kepada suatu variabel atau konstruk dengan cara memberikan arti atau menspesifikasikan kegiatan, ataupun memberikan suatu operasional yang diperlukan untuk mengukur konstruk atau variabel tersebut. (M. Nasir, 1998).

\section{Analisa Regresi Sederhana}

Analisis regresi sederhana dilakukan untuk yang digunakan untuk mengetahui besarnya variabel independen terhadap variabel dependen. Model umum yang terbentuk dalam penelitian ini (Sugiyono, 2002) sebagai berikut :

$\mathrm{Y}=\alpha+\beta 1 \mathrm{X} 1+\mathrm{e}$

Dimana:

$\mathrm{Y}=$ Variabel Dependen

$\alpha=$ Konstanta Regresi (interscrept)

$\beta 1=$ Koefisien regresi

$\mathrm{X} 1=$ Variabel Independen

$\mathrm{e}=$ random error

Variabel yang digunakan dalam penelitian ini adalah :

a. Variabel dependen dilambangkan dengan notasi Y adalah produksi telur.

b. Variable independen dilambangkan dengan notasi X1 adalah harga pakan.

$>$ Jika nilai signifikansi t hitung $<0,05$ maka terdapat pengaruh harga pakan terhadap produksi telur.

$>$ Jika nilai signifikansi t hitung > 0,05 maka tidak terdapat pengaruh harga pakan terhadap produksi telur.

\section{Analisa Finansial Usaha}

a. Analisa Return Cost Ratio (R/C)

Metode $R / C$ rasio adalah alat analisis yang digunakan untuk mengetahui biaya dari suatu penerimaan produksi.

$\mathrm{R} / \mathrm{C}=\frac{\text { Total Penerimaan }(\mathrm{Rp} .)}{\text { Total Biaya }(\mathrm{Rp} .)}$

Menurut Himawati (2006),

Apabila : $\mathrm{R} / \mathrm{C}<1$ maka usaha tersebut dikatakan rugi

$\mathrm{R} / \mathrm{C}>1$ maka usaha tersebut dikatakan untung

$\mathrm{R} / \mathrm{C}=1$ maka usaha tersebut dikatakan tidak untung dan juga tidak rugi

b. Benefit Cost Ratio (B/C)

Rumus perhitungan B/C Ratio (Simanungkalit, Rutkaya 2008) :

B/C Ratio

$$
=\frac{\text { Total Benefit }(\mathrm{Rp} .)}{\text { Total Cost }(\mathrm{Rp} .)}
$$

Dimana :

Apabila : $\mathrm{B} / \mathrm{C}=1$ maka usaha beternak ayam petelur tersebut dikatakan marginal (tidak rugi atau tidak untung)

$\mathrm{B} / \mathrm{C}<1$ maka usaha beternak ayam petelur tersebut dikatakan tidak ekonomis (rugi)

$\mathrm{B} / \mathrm{C}>1$ maka usaha beternak ayam petelur tersebut dikatakan feasible (untung) 
c. Analisa Break Event Point (BEP)

BEP adalah titik batas minimum volume penjualan di mana pada proyek tersebut tidak untung dan tidak rugi. Nilai BEP pada ternak ayam petelur di Desa Kuripan Kidul Kecamatan Kesugihan Kabupaten Cilacap adalah sebagai berikut :

$$
\begin{array}{lll}
\mathrm{BEP}_{\text {harga }} & =\frac{\text { Total Biaya }(\mathrm{Rp} .)}{\text { Total Produksi }(\mathrm{Rp} .)} \\
\mathrm{BEP}_{\text {produksi }} & =\frac{\text { Total Biaya }(\mathrm{Rp} .)}{\text { Harga Penjualan (Rp.) }}
\end{array}
$$

d. Analisa Return on Investment (ROI)

ROI adalah analisis keuntungan usaha ternak ayam petelur yang berkaitan dengan modal yang telah dikeluarkan

$$
\text { ROI }=\frac{\text { Laba Usaha (Rp.) }}{\text { Modal (Rp.) }} \times 100 \%
$$

\section{Kerangka Berpikir}

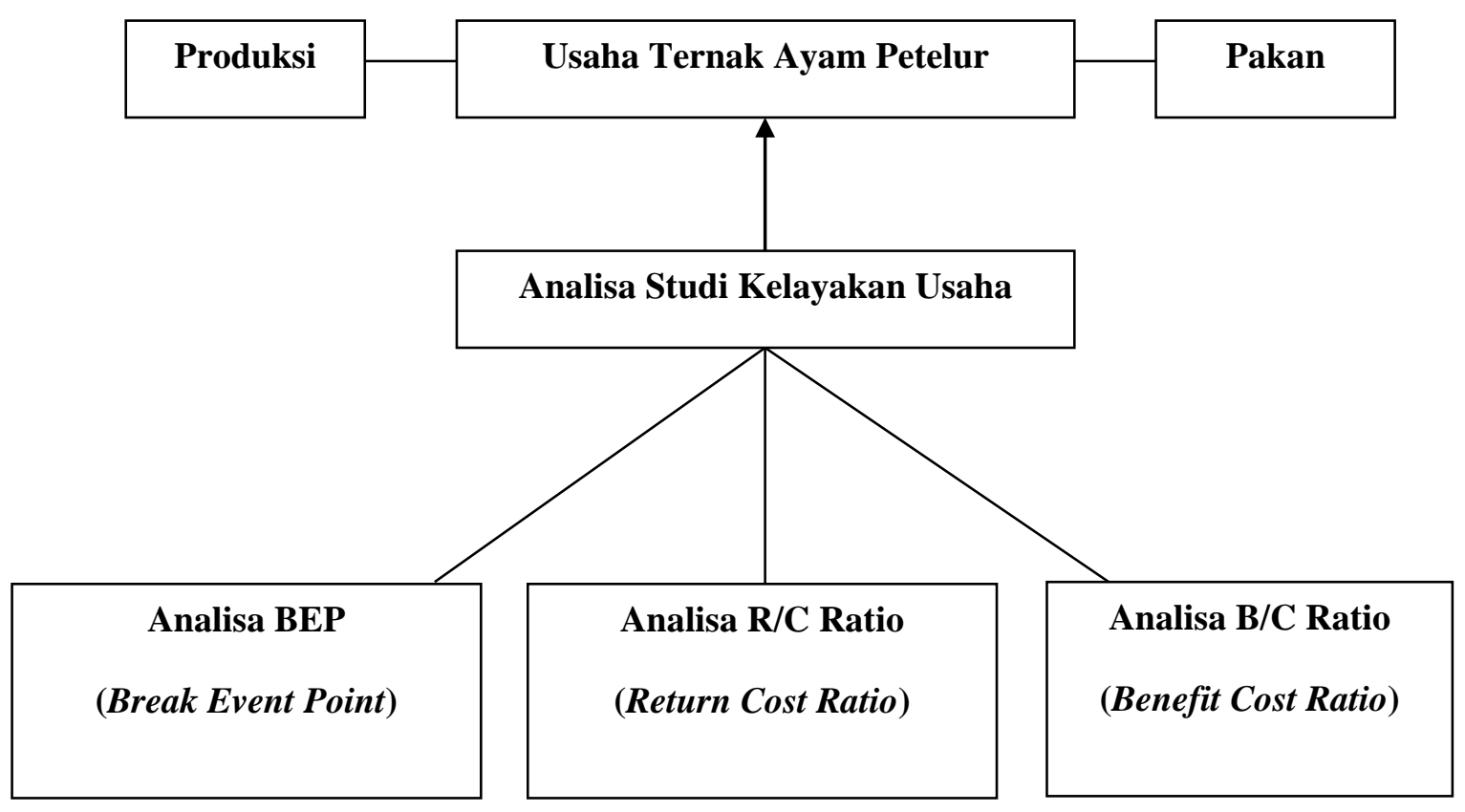

Gambar 2. Model Kerangka Berpikir

\section{HASIL DAN PEMBAHASAN}

\section{a. Analisa Regresi Linear Sederhana}

Untuk mengetahui pengaruh harga pakan terhadap jumlah telur diperoleh hasil perhitungan regresi sederhana pada tabel di bawah ini :

Tabel 1 : Rekapitulasi Hasil Perhitungan Regresi Coefficients $^{\mathrm{a}}$ 


\begin{tabular}{|c|c|c|c|c|c|c|}
\hline \multirow{2}{*}{\multicolumn{2}{|c|}{ Model }} & \multicolumn{2}{|c|}{ Unstandardized Coefficients } & \multirow{2}{*}{$\begin{array}{c}\begin{array}{c}\text { Standardized } \\
\text { Coefficients }\end{array} \\
\text { Beta } \\
\end{array}$} & \multirow[b]{2}{*}{$\mathrm{t}$} & \multirow[b]{2}{*}{ Sig. } \\
\hline & & B & Std. Error & & & \\
\hline \multirow[t]{2}{*}{1} & (Constant) & 92582.361 & 475.069 & & 194.882 & .000 \\
\hline & $x$ & $-3.143 E-7$ & .080 & -1.026 & -3.139 & .009 \\
\hline
\end{tabular}

a. Dependent Variable: $y$

Sumber : Pengolahan Data SPSS 16 (2020)

Berdasarkan tabel regresi linier di atas didapatkan suatu persamaan garis regresi sebagai berikut:

$Y=92582.361-3.143 E-7+C$

Diketahui bahwa nilai signifikansi t sebesar $0,009<0,05$ artinya terdapat pengaruh antara harga pakan terhadap produksi telur. Dengan demikian dapat dikatakan bahwa ada pengaruh harga pakan terhadap produksi telur. Nilai koefisien regresi sebesar -3,139 menunjukkan adanya pengaruh negatif. Artinya jika semakin tinggi harga pakan baik katul, konsentrat maupun jagung, maka akan semakin menurunkan produksi telur yang ada. Hal ini disebabkan karena harga pakan semakin meningkat berarti budget atau dana yang dikeluarkan semakin tinggi sehingga dengan dana yang tetap akan cenderung menurunkan kadar pakan dan berimbas pada produksi telur yang ada.

\section{b. Analisa Finansial Usaha}

Usaha peternak telur memiliki tujuan untuk mendapatkan pendapatan yang maksimal dengan menggunakan faktor produksi yang optimal. Biaya-biaya yang di keluarkan harus di perhitungkan, karena dengan di ketahui biaya dan penerimaan, seorang peternak dapat memperkirakan apakah usaha ternaknya untung atau rugi. Hasil laporan keuangan yang akan dianalisis adalah laporan keuangan selama periode JanuariDesember 2019.

1. Pendapatan peternak telur KR Farm

Pendapatan usaha ternak adalah nilai penerimaan dikurangi dengan total biaya yang di keluarkan selama proses produksi yang dinyatakan dengan nilai uang. Rata-rata produksi KR Farm per hari sebanyak 3.059,80 Kg (49.672 butir) dengan harga Rp. 17.500.

2. Biaya-biaya produksi peternak telur KR Farm

Rincian biaya-biaya dari peternak telur KR Farm, yaitu :

\section{a. Biaya Tetap}

Biaya tetap adalah biaya yang di keluarkan oleh peternak yang besar kecilnya tidak mempengaruhi terhadap hasil produknya nanti, terdiri dari :

- Biaya listrik dan air yang secara bulanan berjumlah Rp. 750.000,-

- Biaya penyusutan kandang

- Biaya penyusutan peralatan

b. Biaya Variabel

Biaya tidak tetap adalah biaya yang besar kecilnya akan berpengaruh terhadap hasil produksinya, terdiri dari :

- Tenaga Kerja

Usaha peternakan ini di bantu oleh 8 orang pekerja, di mana masing-masing pekerja memiliki gaji sebesar Rp. 1.200.000,- per bulan.

- Obat-obatan, vaksin dan vitamin 
Kondisi kesehatan ternak ayam harus tetap dijaga, baik itu dari obat-obatan dan vaksin yang akan diberikan kepada ternak. Rata-rata biaya obat-obatan dan vaksin per bulan sebesar Rp. 52.845.100,- sedangkan untuk biaya vitamin ternak per bulan sebesar Rp. 15.098.600,-.

- Pakan

Konsumsi pakan pada ternak ayam untuk 1 ekor ayam per hari sebanyak 125 gram, dengan harga pakan rata-rata Rp 3.600,- dengan jumlah ternak 75.493 ekor.

Tabel 2. Rata-rata pengeluaran biaya di peternakan KR Farm

\begin{tabular}{|c|c|c|c|}
\hline No & Jenis Biaya & \multicolumn{2}{|c|}{ Jumlah } \\
\hline 1 & $\begin{array}{l}\text { Biaya Tetap } \\
\text { Listrik } \\
\text { Penyusutan Kandang } \\
\text { Penyusutan Peralatan }\end{array}$ & $\begin{array}{l}\text { Rp. } \\
\text { Rp. } \\
\text { Rp. }\end{array}$ & $\begin{array}{r}9.000 .000 \\
113.239 .500 \\
14.761 .575\end{array}$ \\
\hline 2 & $\begin{array}{l}\text { Biaya Variabel } \\
\text { Gaji Pekerja ( } 8 \text { orang pekerja) } \\
\text { Vaksin } \\
\text { Obat-obatan } \\
\text { Pakan }\end{array}$ & $\begin{array}{l}\text { Rp. } \\
\text { Rp. } \\
\text { Rp. } \\
\text { Rp. }\end{array}$ & $\begin{array}{r}115.200 .000 \\
317.070 .600 \\
181.183 .200 \\
6.450 .000 .000 \\
\end{array}$ \\
\hline & TOTAL & Rp. & 7.949 .930 .375 \\
\hline
\end{tabular}

Dari data diatas, dapat dilakukan analisis biaya dan manfaat menggunakan analisis R/C Ratio, B/C Ratio, BEP dan ROI.

Tabel 3. Analisis Biaya dan Manfaat

\begin{tabular}{|c|l|l|l|l|}
\hline No. & \multicolumn{1}{|c|}{ Jenis Analisis } & \multicolumn{1}{|c|}{ Rumus } & \multicolumn{1}{c|}{ Hasil } \\
\hline 1 & $\begin{array}{l}\text { Analisis Return Cost } \\
\text { Ratio }\end{array}$ & $\begin{array}{l}\text { Rp. 21.403.106.660 } \\
\text { Rp. 7.949.930.375 }\end{array}$ & 2,69 \\
\hline 2 & $\begin{array}{l}\text { Analisis Benefit Cost } \\
\text { Ratio }\end{array}$ & $\begin{array}{l}\text { Rp. 13.453.176.284 } \\
\text { Rp. 7.949.930.375 }\end{array}$ & 1,69 \\
\hline 3 & Analisis BEP & $\begin{array}{l}\text { a. BEP Harga } \\
\text { Bp. 7.949.930.375 }\end{array}$ & $\begin{array}{l}\text { (49.672 butir x 365 } \\
\text { hari) }\end{array}$ & 438,49/rupiah/butir \\
\cline { 3 - 5 } & A. BEP & $\frac{\text { Rp. 7.949.930.375 }}{\text { Produksi } 17.500}$ & $454.281,74$ butir \\
\hline 4 & Analisis ROI & $\frac{\text { Rp. 10.661.108.785 x 100\% }}{\text { Rp. 7.949.930.375 }}$ & $1,69 \%$ \\
\hline
\end{tabular}

Dari hasil tabel dapat dibahas :

a. Analisa Return Cost Ratio

Berdasarkan hasil tabel diatas menunjukkan bahwa besaran $R / C$ Ratio sebesar 2,69, yang mana hasil tersebut menunjukkan bahwa $R / C$ Ratio $>1$, artinya usaha peternakan UD KR Farm tersebut feasible (untung).

\section{b. Analisa Benefit Cost Ratio}

Berdasarkan hasil tabel di atas menunjukkan bahwa besaran B/C Ratio sebesar 1,69, yang mana hasil tersebut menunjukkan bahwa $R / C$ Ratio $>1$, artinya usaha peternakan UD KR Farm tersebut feasible (untung). 


\section{c. Analisa BEP}

- BEPharga $_{\text {h }}$ 438,49/rupiah/butir

Harga telur Rp. 17.500/Kg (sekitar 18 butir), jadi 17.500/18 = 972,22/rupiah/butir

Yang berarti bahwa usaha peternakan UD KR Farm dalam menjual telur masih diatas BEP harga.

- BEP produksi $\quad$ 454.281,74 butir

Produksi telur dalam 1 tahun sekitar 18.130.280 butir

Yang berarti bahwa usaha peternakan UD KR Farm dalam menghasilkan telur masih di atas BEP produksi.

\section{d. Analisa $\mathrm{ROI}$}

Hasil ROI $=1,69 \%$

Yang berarti bahwa besaran keuntungan yang diperoleh lebih besar dari modal yang dikeluarkan yaitu sebesar $1,69 \%$.

\section{KESIMPULAN}

Berdasarkan hasil penelitian dan pembahasan di atas, maka dapat ditarik kesimpulan sebagai berikut:

a. Terdapat pengaruh antara variabel Y (harga pakan) terhadap variabel X (produksi telur) pada usaha ternak KR Farm

b. Analisa Studi kelayakan usaha ternak ayam petelur pada KR Farm ditinjau dari analisa biaya manfaat memperoleh nilai $\mathrm{B} / \mathrm{C}>1$, maka usaha ternak ayam petelur tersebut dikatakan feasibility (untung).

c. KR Farm mencapai titik BEP pada saat produksi telur ke $28.392 \mathrm{Kg}$ (454.281 butir).

\section{SARAN}

Berdasarkan penelitian mengenai studi kelayakan ternak ayam petelur, maka dapat disampaikan saran :

a. Pihak KR Farm dapat mempertahankan usahanya yang memiliki kinerja baik dan layak selama ini, jika dilihat dari harga pakan yang cenderung naik maka akan lebih baik menjaga tingkat konsumsi pakan yang ideal agar tidak mengalami kerugian dimana biaya produksi (khususnya konsumsi pakan) lebih besar dari tingkat produksi telur.

b. Pihak KR Farm dapat meningkatkan keuntungan yang diperolehnya dengan cara menambah jumlah ayam petelur pada periode waktu berikutnya, selain itu sebaiknya juga membagi ayam ke dalam beberapa periode usia ayam guna menjaga siklus usia ayam sehingga dapat memperbaiki kualitas telur hasil produksinya. 
c. Untuk menurunkan tingkat jumlah BEP serta mempercepat pencapaian titik BEP, sebaiknya dapat dilakukan dengan cara meningkatkan harga jual telur melalui cara pendistribusian hasil produksi langsung ke pasar tanpa melalui perantara/tengkulak/ pengepul/distributor karena harga jualnya relatif lebih tinggi. Selain itu juga dapat dilakukan dengan cara menurunkan total biaya produksi, seperti pengurangan konsumsi pakan setelah ayam melewati masa titik puncak produksi telurnya.

\section{UCAPAN TERIMAKASIH}

Peneliti mengucapkan terima kasih yang sebesar-besarnya kepada UD. KR Farm, Kuripan Kidul, Kesugihan, Cilacap yang telah berkontribusi dalam menyelesaikan artikel ini.

\section{DAFTAR PUSTAKA}

Abbot, J.C dkk, 1979. "Agricultural Economic and Marketing in the Tropics", Longman Publishing Company, New York.

Anandra, Ahmad Ridhani. 2010. "Analisis efisiensi penggunaan faktor- faktor produksi pada usaha ternak ayam ras pedaging di Kabupaten Magelang". Semarang : Fakultas Ekonomi Universitas Diponegoro.

Biro Pusat Statistik Cilacap, 2013. "Data Sensus Pertanian 2013 Jumlah Usaha Peternakan Unggas".

Dian K.R. 2013. "Kelayakan Usaha Budidaya Ayam Petelur (Analisis Biaya Manfaat dan BEP pada KEANU FARM, Kendal)". Skripsi. Fakultas Ekonomi. Universitas Negeri Semarang. Semarang.

Dinas Peternakan, Kelautan dan Perikanan Kabupaten Cilacap, Tahun 2018.

Ghozali, Imam. 2005. “Analisis Multivariate dengan Program SPSS”. Semarang : Universitas Diponegoro.

Gitusudarmo dan Basri. 2002. “Manajemen Keuangan”. Yogyakarta : BPFE.

Hakiki, Gaib "Konsumsi Kalori dan Protein Penduduk Indonesia dan Provinsi”, Retrieved July 23, 2018, fromhttps://www.bps.go.id/publication/download.html.

Knut Wicksell. 1926. “Interest and Prices”. Ludwig von Mises Institute.

Kotler, Philip. 2000. “Manajemen Pemasaran”. New York: McGraw Hill.

Mongi, H. 2014. "Analisis profitabilitas usaha peternakan ayam petelur bina ternak mandiri di Kelurahan Mapane Kecamatan Poso Pesisir”. Jurnal Agro Peternakan. 11(1). 
Mulyani, Altri. 2013. "Kelayakan Usaha Peternakan Ayam Petelur Kelompok Wanita Tani Ternak "Wanita Karya" Kabupaten Banyumas". Jurnal Pembangunan Pedesaan. 13(2). 89-96.

Mustofa. 2008. “Ekonomi Pemasaran dalam Pertanian”. Yogyakarta : Andi.

Nawawi, Hadari. 1997. "Manajemen Sumber Daya Manusia", Edisi Pertama Gajah Mada University Press.

Rahardi dkk. 2003. “Agribisnis Perikanan”. Yogyakarta; Pendidikan Penebar.

Rasyaf, M. 2002. “Beternak Itik”. Edisi ke -16. Kanisius. Yogyakarta.

Rita, Yunus. 2009. "Analisis Efisiensi Usaha Peternakan Ayam Ras Pedaging Pola Kemitraan dan Mandiri di Kota Palu Provinsi Sulawesi Tengah". Semarang : Magister Ilmu Ekonomi dan Studi Pembangunan

Simanungkalit, Rutkaya. 2008. "Inventaris Makanan Khas Toba dan Strategis Pengembangannya”. Medan: Fakultas Pertanian Universitas Sumatera Utara.

Subagja, Hariadi. dkk. 2017. “Analisis Kelayakan Usaha Peternkan Tradisional Itik Petelur di Kabupaten Jember”. Jurnal Ilmu Peternakan Terapan. 1(1). 39-44.

Sugiyono, 2002. “Metode Penelitian Bisnis”. Bandung: CV Alfabeta. 